\title{
První generace lokálních a regionálních politických lídrü'
}

\author{
The First Generations of Local and Regional Political Leaders \\ Dan Ryšavý
}

\begin{abstract}
This article addresses the question of the first generations of local and regional politicians in the Czech Republic after the Velvet Revolution in 1989. A brief review of the changes in the political and economic elite is followed by discussion of the establishment, the personnel structure and other characteristics of the first local leaders. They were not people who were born and grew up at the same time. However, they were all connected to the renewal of local government institutions. Their primary task was to learn many related roles and to acquire necessary skills. A growing gap between the leaders' and citizens' attitudes is expected with the rise of the next generation of local politicians.

The first regional leaders who came to power after the elections in 2000 differ from the first generation of local leaders in terms of their personal experience with various governmental bodies. They have expressed a higher level of interpersonal and institutional trust than the citizens, and a higher selfawareness. Their newly established position between the local and the national politicians has gradually changed the whole political system. In this respect they are beginning to have an impact on both local and national leaders, and are starting to play a role at the European level.
\end{abstract}

KEY WORDS Generation, political leaders, political elite, learning process, local government, regional government, the Czech Republic.

„Československo se po dvaceti letech ocitlo opět na historické křižovatce dík lidovému hnutí, k němuž se rychle připojují všechny generace a vrstvy obyvatelstva i většina dosud existujících společenských organizací,“ praví se v provolání Občanského fóra z 23. listopadu 1989. ${ }^{2}$ Týden po vypjaté konfrontaci demonstrujících studentů s represivními složkami komunistického režimu usiluje provolání o co nejširší spojení všech „nás“, bez ohledu na věk a formativní zkušenosti, společenské postavení i členství v různorodých organizacích. Text pokračuje slovy „toto hnutí je hnutím obou našich národů“. Než dojde k podstatným změnám ve státě i v životě jednotlivých občanů, je třeba zabránit nástupu konkurenčních zdrojů identit ${ }^{3}$ a stížností na ,ukradenou revoluci“, at’ už ze strany studentů, divadelníků či intelektuálů.

Sociální studia. Fakulta sociálních studií Masarykovy univerzity, 1-2/2007. S. 115-130. ISSN 1214-813X.

1 Text navazuje na dokončený projekt „Proměny lokálních politických elit na venkově a malém městě“ (GA ČR 403/03/D241).

2 Zdroj: Informační servis 1989, č. 5. in Respekt '90-00: deset let. 2000. CD-ROM. Praha: R-Presse s.r.o.

3 Na spory „o pomlčku“ v názvu federativního státu zbylo dost času později. Naopak v německém př́padě heslo „Wir sind das Volk!“”, o které demonstranti z podzimu 1989 připravili vládnoucí 
Cílem předložené stati není polemika s tím, zda se listopad 1989 stal historickou křižovatkou ${ }^{4}$. Potřeba autorů výzvy překlenout generační rozdíly v momentě střetu s hroutící se mocí minulých vládců byla pochopitelná. Na jedné straně demonstrující studenti, na druhé jejich rodiče, z nichž se mnozí museli kdysi pod nátlakem rozhodovat, zda srpnové události roku 1968 označí za okupaci či bratrskou pomoc, a konečně prarodiče, kteří po válce budovali nové Československo, nebo přicházeli o majetek a postavení - ti všichni nemohli posuzovat rychlý sled událostí podzimu 1989 ze stejného úhlu. Bránily jim v tom jejich zkušenosti. Ale proč provolání uvádí „opět po dvaceti letech“? Kdo všechno by byl vyloučen z rychle budovaného a co nejšířeji pojatého kolektivního MY, kdyby se v prohlášení objevilo spojení „po více než čtyřiceti letech“? Neoctla by se velká skupina občanů v roli ,generace ztracené“? Symbolicky řečeno, volba dvacítky let jako mezníku stačila na to, aby se o pár měsíců později objevily známky rozčarování u mladších ročníků. V týdeníku Respekt (22. 8. 1990) je formuloval tehdy trriatřicetiletý Martin Fendrych: „Člověka mé generace - je mi přes třicet - nemůže nezarazit fakt, že do většiny vysokých funkcí se vyšplhali lidé z bývalých řídících, vyšších i nejvyšších struktur, tedy lidé, kteří zastávali různá vedoucí místa okolo osmašedesátého roku. Proběhla přímo fantastická erupce ,dubčekovské‘ generace. Po dvacetiletém půstu se hladově vrhli ,na svá místa‘. Pak není tedy divu, že se mnoho neděje, že všechno trvá dlouho a mnohdy nedojde k ničemu." Nedlouho na to se Fendrych stal mluvčím federálního ministerstva vnitra a po parlamentních volbách v roce 1992 dlouholetým náměstkem jen o málo staršího českého ministra vnitra Jana Rumla. ${ }^{5}$

Vyslovený názor i pozdější kariéra Martina Fendrycha nevytvářejí pravidlo, jen poukazují na to, že optika generací má smysl i při studiu proměn politiky a politiků. V tomto textu nejprve připomeneme teorie a výzkumy proměn politických elit, které operují s věkem či volně pojatou generační spřízněností, a poté se zastavíme u autorů, kteří při hledání rozdílů mezi generacemi počítají s odlišnými formativními zkušenostmi. Hlavní pozornost je následně věnována prvním kohortám lokálních a regionálních politiků v České republice a pojmenování jejich specifických, generačních charakteristik.

\section{Proměny polistopadových elit}

Proměně polistopadových elit byla věnována řada speciálních teorií a výzkumů (viz například Best a Becker 1997, Bozóki 2003). Nejblíže ke generačnímu pohledu měla zřejmě Erszébet Szalai (1994), která rozdělila dřívější elitu na staré byrokraty a mladé technokra-

Socialistickou stranu, brzy vystřídala jeho nacionální podoba „Wir sind ein Volk!“, což někteří vykládali jako zradu „třetí cesty“ demokratického socialismu (Pfaff 1996).

4 Příčilo by se to vlastní biografii autora, $v$ té době čerstvého vysokoškoláka, který si ale ještě při maturitě neuměl představit, že by studoval marx-leninskou sociologii. Po dvou letech následovala výměna věd přirodních za sociální, s jejichž pomocí bylo snazší hledat odpovědi na osobní otázky. Inu, formativní období.

5 Oba spojovalo mimo jiné to, že se do svých vysokých funkcí dostali od novin, ke kterým se Jan Ruml chtěl podle svého prohlášení z jara 1990 vrátit hned, jak promění jemu svěřený úřad z obávaného místa plného estébáků. V mediální oblasti se po roce 1989 nejsnáze uplatnila řada mladých aktivních lidí. 
ty ${ }^{6}$ Nešlo přitom jen o věkové rozlišení. První skupina získala mocenské pozice v padesátých a šedesátých letech především svou politickou loajalitou, druhá se do pozic dostávala až v sedmdesátých a osmdesátých letech, mimo jiné také pro svoji kompetenci. Szalai předpokládala, že mladí technokraté postupně ztráceli víru ve věc socialismu a začali podporovat změny zvláště v hospodářské oblasti. Vzhledem ke svému vzdělání a kvalifikaci pak mohli snáze projít obdobím chaosu po roce 1989 a setrvat ve funkci, nebot' byli nenahraditelní pro udržení chodu různých institucí.

Podle velkého mezinárodního výzkumu sociální stratifikace a rekrutace elit (Szelenyi a Treiman 1991) odpovídala uvedeným hypotézám především proměna ekonomických elit, u nichž často docházelo k tzv. revoluci náměstků (Hanley a kol. 1996). Personální proměna politických elit byla daleko radikálnější. V českých zemích ji navíc posiloval fakt, že se zdejší politické špičky po normalizačních čistkách věkově poměrně výrazně uzavřely. Vytvořily svého druhu ,generační zátku“ (Machonin a kol. 2006: 56), která byla „v roce 1989 už vưčihledně morálně vyčerpána“ (Kabele 2005: 284). Ke generační výměně ve smyslu nástupu mladších věkových kohort tak došlo dříve $\mathrm{v}$ politické než $\mathrm{v}$ ekonomické sfére. Příležitost ke změně s sebou nesly $\mathrm{v}$ jedné sféře volby, $\mathrm{v}$ druhé pak rưst soukromého sektoru a také zahraniční investice. $\mathrm{K}$ ilustraci proměn politických elit postačí uvedený výčet funkcí Martina Fendrycha. Celkovou situaci komentoval Milan Tuček slovy: „Nová elita je pochopitelně mladší... Je to částečně způsobeno tím, že značná část reprezentantů původního Občanského fóra (mnozí disidenti a zejména tzv. ,osmašedesátníci`) fakticky přestali být součástí politické elity nově vytvořené České republiky“ (Tuček 1996: 162). Omlazování ekonomických elit posléze zaznamenala jak další výzkumná šetření, ${ }^{7}$ tak mediální pozorovatelé, kteří si všímali především viditelných a rychlých kariér třicátníkủ etablujících se ve vrcholových pozicích velkých společností. Někdy až zjednodušujícím způsobem poukazovali na to, že hlavní roli nehrál věk, ale zejména zkušenost. ${ }^{8} \mathrm{Na}$ jedné straně šlo o obeznámenost staronových ekonomických elit s minulým režimem a s principy fungování tehdejšího hospodářství, na straně druhé o odkojenost nových elit globalizující se současností.

Relativně rychlou a výraznou personální výměnu politických elit na začátku 90 . let později vystřídala jejich rostoucí stabilizace a s ní spojené postupné stárnutí politické elity. Ač šlo o pochopitelný jev, někteří badatelé jej vnímali negativně. Michal Illner došel při komparaci dvou výběrových šetření českých starostů k závěru: „Výraznou a nepochybně nežádoucí změnu však představuje podstatné zhoršení věkové struktury starostů, jejichž polovina je nyní starší padesáti let a jejich průměrný věk se tak vyšplhal ze 46 let v r. 1991 na 50 let v r. 1997“ (Illner 2001: 258-9). Pavel Machonin s kolegy označili převahu staré a starší

6 S generacemi operuje také teorie přerušovaného zburžoaznění Ivana Szelenyiho (1988), která zdůrazňuje genealogickou svázanost významných osob z před- a po-komunistického období.

7 Ve výzkumu elit z přelomu let 2003 a 2004 stoupá průměrný věk elit následovně: mediální, ekonomické, politické, administrativní a kulturní (Frič a kol. 2005).

$8 \quad$ Za př́klad poslouži dva titulky z ekonomické př́lohy deníku Lidové noviny. První je z 6. 4. 2000: „Bývalí marxisté vzali kapitalismus za svůj. Deset let po listopadové revoluci někdejší komunisté vytlačují podnikatele Klausovy éry“, druhý pak ze 3. 5. 2001: „Nová manažerská elita mění návyky. Nejdůležitějším předpokladem vrcholných manažerů v české ekonomice již nejsou ,známosti‘, ale kvalitní vzdělání“. 
střední generace v politické elitě z let 2003-2004 za povážlivou a chápali ji jako „signál jisté averze mladých lidí k politice, jak je dnes provozována... také však neochotou politiků z první fáze transformace uvolnit místo pro mladší lidi““(Machonin a kol. 2006: 57)9.

Z uvedených citací je zřejmé, že autoři zabývající se proměnami polistopadových elit nakládají s pojmy věk a generace poměrně volně. V následující pasáži se pozornost přesouvá $\mathrm{k}$ autorům, kteří pojem generace důkladněji operacionalizují pro potřeby kvantitativních šetření. V nich se mimo jiné pokouší odlišit vliv věku a příslušnosti k určité generaci na postoje a chování dotazovaných.

\section{Věk, generace a perioda}

Velké kvantitativní výzkumy obvykle problematiku generací zjednodušují na testování odlišností různých věkových kohort nebo se snaží doložit rozdíly v hodnotách, postojích či chování u předem definovaných generací. K nejznámějším příkladům patři hypotéza tiché revoluce Ronalda Ingleharta (1977), který zkonstruoval dvě generace na základě modelu s hypotézami nedostatku (Maslowova hierarchie potřeb) a socializace. Posun od materialistických k postmaterialistickým hodnotám vysvětluje postupným nahrazováním generace dospívající v období hospodářské krize a války mladší generací, která dorůstala v období poválečné prosperity. Henk Becker rozlišil a pojmenoval čtyři generace (viz např́klad Becker 1992). Své teze o generacích předválečné (již tvořili lidé narození v letech 1910 až 1930), tiché (generace narozených v letech 1930 až 1940), protestní (1940 až 1955) a ztracené (1955 až 1970) testoval především v Nizozemí. ${ }^{10}$ Beckerův model zahrnuje vedle socializace a relativního nedostatku vliv masových médií, počítá také jak s manifestními, tak latentními generacemi. Tessler, Konold a Reif (2004) k rešerši soupeřících i pozměňujících hypotéz dodali, že politické generace mohou být relativně ojedinělé. Některá historická období přinášejí trvalé generační efekty, jiná nikoliv. Podobně některé postoje z formativních let přetrvávají a jiné ne. ${ }^{11}$

Vliv věku, periody a generací (věkových kohort narozených a dospívajících v určitém období) na postoje lokálních politiků studoval Michiel De Vries (2005). Zjednodušeně řěeno, teorie spojené s věkem předpokládají, že starší lidé přemýšlejí odlišně než mladí, což lze vysvětlit odkazem na fáze životního cyklu. Nedojde-li k omlazení či ke stárnutí kádru politiků, neměly by se jejich postoje v čase měnit. Klasická teorie generací (sahající k Mannheimovi) očekává, že po uplynutí formativního období zůstanou postoje stabilní. Nastoupí-li

9 Připomeňme iniciativu někdejších studentských vůdců „Děkujeme, odejděte!“ z podzimu 1999 namířenou především proti Václavu Klausovi a Miloši Zemanovi. Z generačního hlediska mj. narazila na fakt, že se někteří z dřívějších studentů již etablovali ve vysoké politice (např́iklad Ivan Langer). Jedním z mála odstoupivších politiků byl Jan Ruml, který ač spíše vrstevník vyzyvatelů, uváděl morální apel této výzvy mezi důvody odchodu z pozice předsedy Unie svobody.

10 De Vries (2005) ke čtyřem zmíněným generacím dále přiřadil pragmatickou generaci zrozenou v sedmdesátých letech, která viděla kolaps Sovětského svazu. Dosud neznámou generaci $X$ může spojovat zážitek útoku na newyorská dvojčata a zkušenost války s terorismem.

11 Ve své studii provedené v Alžírsku došli na základě údajů z výzkumu veřejného mínění z roku 1995 k závěru, že společné postoje charakterizují jen generaci dospívající v prezidentském období Houari Boumedienneho (1965-1978). 
nová generace, nemělo by dojít ke změně politických hodnot a norem kvůli omlazení samotnému, ale kvůli odlišné socializaci nové generace politiků. Teorie akcentující různé periody vychází z předpokladu, že jakákoliv vláda nemůže řešit všechny problémy simultánně a musí určovat priority. Urgentnost problémů ovlivňují ekonomické okolnosti, dominantní politická kultura, pozornost médií atd. V závislosti na nich se pak mohou měnit také postoje a přesvědčení politiků. Jednou je zdůrazňována efektivnost, podruhé participace a demokratizace, jindy zase výkonnost. Sada názorů charakteristická pro sedmdesátá léta se lišila od názorů let osmdesátých, od období po studené válce či po 11. září 2001.

Ve svém vlastním výzkumu se De Vries (2005) snažil ukázat, které postoje jsou typické pro určitá klasifikační kritéria - v tomto prŕípadě pro věk, periodu či generaci. Využil dat z mezinárodního výzkumného projektu Democracy and Local Governance a porovnal odpovědi vzorku lokálních politiků a místních administrativních špiček z Ruska, Běloruska, Litvy, Nizozemí a Švédska zachycené v letech 1989 až 1991, 1995 až 1997 a 2000 až 2001. S pomocí diskriminační analýzy došel k závěru, že vliv periody je vždy silnější než vliv generací a věku. Jinými slovy, z postojů a hodnocení problémů respondentů lze s největší přesností určit, $v$ jakém období vyjadřovali své mínění a méně už, do jaké generace či věkové skupiny náleželi. Vliv periody na změnu hodnot byl zvláště silný tam, kde se periody odlišovaly významným posunem v naléhavosti společenských problémů, a méně výrazný tam, kde problémy zůstávaly stabilní.

Při výkladu analytických technik nešel De Vries do takových podrobností, aby bylo možné kriticky zhodnotit jeho postup. Výběr zemí omezovala dostupnost dat. Když se však na jedné straně ocitlo Bělorusko a Švédsko jako země, jež oproti ostatním spojuje stabilita nízké nebo naopak vysoké urgentnosti problémů, které musí lokální reprezentace řešit, vzbuzuje to určité pochybnosti. Autor navíc na konci textu sám relativizoval to, $\mathrm{k}$ čemu došel. Zjištění, že postoje politiků se př́liš nemění s věkem či př́islušností ke generaci, ale především s dobou, vyznělo jako oportunismus. Nejpríhodnějším závěrem podle De Vriese proto je, že se na lokální úrovni objevil nový typ vůdcovství; typ, který musel jednat za jiných podmínek a který se od předchůdců svými politickými názory odlišoval zejména $\mathrm{v}$ těch zemích, kde se podmínky změnily nejvýrazněji. „Není důležité, že nová generace nebo mladší kádry okupují volné pozice, ale že podmínky, zdá se, určují, kteří členové generace nebo věkové skupiny se stanou členy lokální elity. $\mathrm{V}$ zemích zažívajících drastické politické změny simultánně provázené změnami $\mathrm{v}$ naléhavosti sociálních problémů to budou zřejmě především ti jedinci, kteří si uvědomují složitost doby a bez obtíží nesou změnu politického větru“ (De Vries 2005: 13-14). Takový závěr pak může zpochybňovat generační hypotézy jen v jejich zjednodušené pozitivistické podobě. Stěží však může ohrozit Mannheimovu koncepci počítající s navzájem soupeřícími generačními jednotkami.

\section{První generace lokálních lídrů v České republice}

V dalších úvahách se soustředíme na představitele menších obcí, které mezi českými sídly tvoří naprostou většinu. Má to svou logiku, nebot’ reprezentanti největších měst bývají často zařazováni do politických elit celostátního či alespoň regionálního významu. Označení „lokální“ dostává podstatně odlišný obsah, jedná-li se o vesnici či malé město na jedné straně, 
anebo na druhé straně o statutární město, jež se samo dělí na městské obvody. K nalezení generačně specifických charakteristik lokálních lídrů mohou stejně dobře posloužit výzkumy kvantitativní i kvalitativní povahy. ${ }^{12}$ „Generační distinkce se zpravidla projevují v jemných detailech, ne vždy, u všech a za všech okolností,“ uvedl ve svém posudku jeden z recenzentů tohoto textu. Lze s ním souhlasit i v tom, že nejde předně o změření mohutnosti odlišností, ale o určení specifik, nebot' i ony jemné detaily „,mohou být stále důležité pro způsoby sociálního (politického) jednání“،.

Výzkumníci, kteří po roce 1989 zkoumali obnovu místní samosprávy ve střední Evropě, očekávali, že ,první generace lídrů nastupujících po zásadní změně režimu bude pravděpodobně formovat nové instituce, a tím pádem i určovat vzorce chování přinejmenším v dohledné době“ (Offerdal a kol. 1996: 105, kurzíva DR). Dostáváme se tu k odlišnému pojetí generace, v němž nemusí jít o spojení věkem a zkušeností z formativních let, ale o spojení osob s právě stvořenými samosprávnými pozicemi. ${ }^{13}$ Důležitost adjektiva ,první je dána tím, že lídři dostali možnost naplnit role spojené s pozicemi konkrétním obsahem. Namísto věku a zkušenosti osob nastoupilo jako kritérium vymezující generaci spíše stáří a dosavadní praxe samosprávných institucí, obé jdoucí k nule. Nebylo možné jednoduše a př́mo navázat na tradici místní samosprávy, jak se vyvíjela od dob Rakouska přes meziválečné období. Poválečné nahrazení samosprávy národními výbory, které byly posléze začleněny do hierarchie státní správy, bylo z hlediska lidského věku př́liš vzdálené na to, aby první polistopadoví starostové a radní mohli využít zkušeností svých vzdálených předchůdců. ${ }^{14}$

Podobně jako na parlamentní úrovni i v lokální politice došlo po roce 1989 k výrazné cirkulaci, personální diskontinuita ovšem rostla s velikostí obce. Voleni byli především kandidáti, kteří nebyli úzce spojeni s minulým režimem a zároveň byli mezi lidmi známí (Offerdal a kol. 1996), aktivní (Haukanes 2004). Nezřídka šlo o ty, kteří do lokální politiky vstoupili až po výzvě svých známých, přátel. Obecně patřili tito lidé k respektované části komunit, měli za sebou úspěšný profesní a rodinný život, byli dobře usazení ve svých místech. Museli projít několika výběrovými kroky - dostat se na kandidátku, osvědčit svou „,volitelnost“, a pokud chtěli být opakovaně zvoleni, museli dobře vycházet s ostatními zastupiteli i voliči (Surazska 1996: 130). Přes mnohé rozdíly spojovalo první lokální politiky to, že jejich předchozí zkušenosti a aktivity, tedy často právě to, proč byli osloveni a voleni, jim nebyly mnoho platné k výkonu funkcí, které převzali. Všichni se dostali do situace, v níž jim nezbývalo, než se učit, a to ,za pochodu“. Proti této tezi je možné vznést dvě námitky.

12 K zakladatelským pracím v oblasti lokální demokracie patří sborník Baldersheima a jeho kolegů (1996). Přináší výsledky mezinárodního projektu Local Democracy and Innovation, jenž se opíral především o standardizované dotazování jak místních představitelů, tak občanů. Hojné jsou př́ípadové studie (např́klad Illner 1992, Kandert 2004). Sepsané vzpomínky prvních starostů analyzovala Surazská (1996). Z rozhovorů autora s představiteli menších obcí pochází citáty v dalším textu.

13 Latinské sloveso generó znamená nejen plodit či rodit (odtud pokolení), ale také stvořit.

14 Diskontinuitu spojenou s návratem $\mathrm{k}$ dávné tradici zdůraznili politologové zkoumající instituci obecních voleb. V Balíkově stručném přehledu vývoje obecního volebního práva následuje po kapitolce týkající se let 1919-1938 oddíl přibližující obecní volební právo po roce 1989 (Balík 2003). Analýze nového počátku lokální politiky se však s explicitním odkazem na nevykrystalizovanost politické scény političtí vědci často vyhýbali. 
První zdůrazňuje, že mezi prvními porevolučními reprezentanty obcí byli zastoupeni, byt' v menší míře a častěji v malých obcích, lidé se zkušenostmi ve správě obce. ${ }^{15}$ Vzhledem $\mathrm{k}$ rozsahu a hloubce změn $\mathrm{v}$ činnosti obecních úradů ve srovnání se systémem národních výborů však tyto zkušenosti velmi rychle zastarávaly. V prvním volebním období byl mj. zaveden nový systém financování místní správy. Obce získaly majetek, který však často musely složitě dohledávat a prokazovat a po předání se s ním seznámit a začít o něm rozhodovat. Změnila se organizace úřadů, bylo třeba naučit se rozlišovat úkoly samosprávy a přenesené státní správy. Mnoho problémů přinášela potřeba vydávat vyhlášky ke správě obce tak, aby nebyly okresními úřady rušeny jako nezákonné. Reprezentace obcí stály před úkoly zpracování územních plánů, vytváření př́spěvkových organizací, starost o školy, knihovny atd.

Druhou námitku lze formulovat tak, že zásadními proměnami neprošel pracovní život jen lokálních politiků, ale většiny občanů. Leč málokdo byl při výkonu své práce na očích veřejnosti do té míry, jako vedení radnic. Relevantnější je spíše otázka, nakolik byli občané schopni práci svých představitelů posoudit a podle ohodnocení pak také jednat. „V systému, ve kterém je nejdůležitějším politickým zdrojem osobní důvěra, se mohou vztahy občanů k elitě snadněji řídit vzorci klientely než spoléháním se na institucionální procedury, "varovali Baldersheim a Illner (1996: 237). Zřízení místní samosprávy a zvolení nových představitelů nemuselo automaticky vést ke změně převládajících praktik, které byly nezřídka založené na principu „náš úř̌edník - náš pán“ (Malíková 1997). Pozice v lokální politice je pozicí mocenskou a jako taková lákala držitele ke zneužití pravomocí v osobní prospěch, k získání výhod pro příbuzenské klany či místní kliky. Přes případy doložené či častěji tušené korupce a podobných praktik nelze zneužívání pravomocí považovat za charakteristický rys první generace lokálních lídrů. Obecněji trpěly výkony prvních reprezentací spíše tím, že proti sobě nebo uvnitř svých stran a vládnoucích koalic neměly kvalitní a trvalou oponenturu, která „znamená věci domýšlet, pojmenovávat, vyjednávat, protivit se druhým, což ne vždy vyvolává sympatie..." (Kabele 2004b: 211). ${ }^{16}$

Rozsáhlé výzkumy z první poloviny devadesátých let ukázaly, že novými představiteli obcí byli ve vysoké míře muži středního věku se zaměstnáním bílých límců a s vyšším formálním vzděláním. Jinými slovy, sociálně-demografické složení nové lokální politické elity odráželo složení občanů v mnohem menší míře, než tomu bylo u dřívější elity (Offerdal a kol. 1996: 114, 139). V tomto ohledu stačily jediné volby k tomu, aby lokální reprezentace dospěly do podoby blízké svým protějškům z tradičních demokratických zemí. Na rozdíl od nich však čeští lokální politici neměli čas se pro své funkce dlouhodoběji připravovat, učit se na úspěších i nezdarech svých předchůdců. Jak bylo výše zdůrazněno, učení se mnoha novým rolím probíhalo za pochodu.

15 V prvním období se vyčlenily dva charakteristické typy obecních představitelů - ve větších obcích převážili „,nováčci“, tedy osoby zcela bez zkušeností, v menších obcích se uplatnili i „staří kozáci“, tj. lidé se zkušenostmi, nikoli však př́mo představitelé „starých struktur“ (srv. Illner 1992).

16 „V českých laických i odborných kruzích míváme po ruce vždy rychlé vysvětlení selhání při vládnutí: jsou jimi chabé morální profily vládců. Př́ípad Filipova, kde morální kredit starosty - obrovské nasazení, neúplatnost, snaha o nestrannost a službu veřejnosti - byl mimo pochybnost, však ukazuje, že problém dědictví komunismu i zvládání nároků otevřené společnosti byl podstatně složitějšsi'“ (Kabele 2004b: 211-212). 
Překvapivé bylo pro výzkumníky zjištění, že bez ohledu na nízkou míru sociální reprezentativnosti nových lokálních elit existovala velká shoda mezi postoji občanů a zastupitelů (Offerdal a kol. 1996: 140). Nová osazenstva radnic se chtěla zasloužit o své obce. Řada starostů v sepsaných vzpomínkách řadí mezi největší úspěchy znovunabytí samostatnosti (Surazska 1996), které bylo zvláště v tehdejším Československu relativně snadnou a hojně využívanou cestou, jak se odstřihnout od minulosti. ${ }^{17}$ Lokální lídři také kladli velký důraz na odkaz dávné obecní samostatnosti, snažili se navázat na „zdravé“ lokální kořeny, připomenout zlaté časy obcí (srv. Surazska 1996). Radnice vydávaly kalendáře s historickými pohlednicemi, vycházely reprinty místopisných knih z 19 . a počátku 20 . století, v jinak necírkevním státě se opravovaly drobné sakrální památky atp. ${ }^{18}$ Jinou cestu vstř́c občanům představovalo pokračování v budovatelských praktikách někdejších národních výborů (Kabele 2004a). ${ }^{19}$ Pokračující plynofikace, rekonstrukce kanalizací, stavby čistíren odpadních vod, opravy silnic atp., to vše byly důvody, proč se obce výrazně zadlužovaly, ale nikdo nebyl takovým vývojem př́liš překvapen. Přijímané úvěry byly $\mathrm{v}$ očích voličů snadno ospravedlnitelné, nebot' šlo především o investice do zanedbané infrastruktury. V době, nad níž se vznášel s ekonomickou transformací spojený slogan „o utahování opaskư“, se znovu otevíraly dvoutř́ídky a jiné malé školy, politika nízkých poplatků a pronájmů podporovala drobné podnikatele i jednotlivé občany (Ryšavý 2004).

Přináležitost $\mathrm{k}$ určité generaci (ale také třídě) podle Mannheima staví jedince do určité pozice $\mathrm{v}$ sociálním a historickém procesu, a tím vymezuje specifický rámec jejich potenciálních zkušeností a predisponuje je $\mathrm{k}$ určitému způsobu myšlení, prožívání a historicky relevantnímu jednání (1952: 291). S určitou dávkou zjednodušení lze říci, že jádro první generace lokálních politiků podřizovalo svůj pohled na svět tomu, co podle nich bylo dobré pro obec. U mnoha z prvních lídrů do pozadí ustoupila rodina, řada $\mathrm{z}$ nich obětovala šanci na postup v zaměstnání odpovídající jejich kvalifikaci. Ti, kteří neodolali lákavějším nabídkám v privátním sektoru či státních službách, odcházeli totiž mezi prvními.

Nejde o to kreslit idylický obrázek lokální politiky. Dobré pro obec mohli chtít všichni, ale horší bylo shodnout se na tom, co to konkrétně znamená. Výše zmíněná překvapivá shoda $\mathrm{v}$ postojích občanů a reprezentantů mohla být výsledkem chybějící diskuse o politic-

Lavina rozpadů v minulosti integrovaných obcí započala již před prvními obecními volbami. Proto je na místě zmínit i opačný vztah mezi osamostatněním a vznikem lokálních elit. „Znovu získaná autonomie postavila do vedení obcí nové iniciativní elity, posílila demokratickou legitimitu místní veřejné správy a pomohla změnit vzhled českého venkova“ (Illner 2006a: 12). Ve více než dvou tisících nových obcí dostalo šanci realizovat své plány na dvacet tisíc obecních zastupitelů (Vajdová a Čermák 2006).

18 Složitější cestu měly iniciativy připomínající zmizelé součásti dřivější totožnosti a svébytnosti obcí - vyhlazení židovského obyvatelstva, odsunutí německých občanů atp. Spíše než radnice se jich ujaly neformální sdružení občanů a různé neziskové organizace.

19 Kabele tak označuje situaci, v níž se radnice namísto role správce prosazuje jako (nerozvážný) investor. V př́padě Filipova, který podrobně studoval, tak zprvu šlo o pokračování v investičních akcích plánovaných či započatých již před rokem 1989. Další rozšiřování budovatelských praktik s ne vždy zajištěným krytím spolu s nepříznivými okolnostmi, na něž radnice neměla vliv, přivedlo obec do finanční krize a posléze vyústilo ve výměnu jejího vedení. 
kých otázkách (Offerdal a kol. 1996: 141) či naopak konfliktů snadno přenášených do osobní roviny (srv. Surazska 1996: 132, zvláště citace starostky obce Samotí̌̌ky). Různé skupiny i jednotlivci uvnitř samospráv spolu často neuměli nebo nechtěli komunikovat. Řada nových představitelů se svých postů a mandátů pro neshody vzdala, dráhu dalších ukončily důsledky nekompetentních rozhodnutí, často jen formálně schvalovaných zastupitelstvy. Situace v mnoha obcích byla přinejmenším do druhých obecních voleb v roce 1994 vrtkavá, mimořádné volby starosty či celého zastupitelstva nebyly výjimkou. Jestliže Illner posléze napsal, že „starostové si uvědomují nutnost spolupráce s ostatními významnými místními aktéry a jsou schopni realisticky určit, o které subjekty se jedná“ (2001: 270), právem spojil posuny ve vývoji názorů na místní politiku s procesem učení. ${ }^{20}$

Rozchod názorů a postojů občanů a jejich lokálních reprezentantů by mohl představovat mezník oddělující první generaci lídrů od generace následující. Bez paralelních šetření místních vůdců a mínění veřejnosti však nelze jednoduše zjistit, zda $\mathrm{k}$ něčemu takovému došlo či dochází. ${ }^{21}$ Přinejmenším se však pro takový názorový rozchod už delší dobu otevírá prostor dokumentovaný paradoxní situací. Občané se „na jedné straně o místní politiku př́liš nezajímají, neangažují se v ní a mají dojem, že se ani angažovat nemohou, na druhé straně jsou však $\mathrm{s}$ touto politikou a s místními orgány poměrně spokojení a projevují jim důvěru“ (Illner 2001: 269). Realisticky tuto situaci vnímají i lokální elity. Uznávají důležitost účasti občanů v lokální politice i mimo volby, ale jejich zkušenosti potvrzují nezájem občanů o práci vedení obce (tamtéž).

Na rostoucí názorové štěpení poukázal Jerzy Wiatr (2003) v sousedním Polsku, které má v oblasti lokálních elit mnohem bohatší výzkumnou tradici. Dle šetření z léta 2001 se nejvýraznější rozdíly v názorech veřejnosti a vůdců týkaly sociální a ekonomické politiky státu, a to ve spojení s reformami územní správy, vzdělávání, zdravotnictví a důchodů, které po parlamentních volbách v roce 1997 zaváděla středo-pravá vládní koalice. Většina veřejnosti se vyjadřovala proti-kapitalisticky a egalitářsky, lídři upřednostňovali kapitalistickou ekonomiku a orientaci na ekonomický rozvoj. Občané a lídři se také lišili v chápání demokracie. Vůdci chápali demokracii legalisticky a procedurálně, většina veřejnosti pak paternalisticky a do značné míry autoritářsky. ${ }^{22}$ Veřejnost většinou negativně hodnotila i čtyři zmíněné reformy. Relativně nejlépe prošla reforma územní správy. Lokální vůdci byli také kritičtí ke zdravotnické, vzdělávací a důchodové reformě, ale reformu samosprávy hodnotili většinou pozitivně.

V České republice se o reformách ve zmíněných oblastech tu a tam mluví, ale konkrétní kroky byly doposud učiněny prakticky pouze v rovině územně správní reformy. Sféru samosprávy rozšřřila nově ustavená krajská úroveň, systém státní správy pozměnilo zrušení okresních úřadů a vytvoření soustavy obcí z rozšířenou působností. Každý z reformátorů

20 Dnes už bývalá starostka jedné menší obce v jižních Čechách pojmenovala jednotlivé fáze práce starosty. První období se starosta „učí“, ve druhém „dělá hodně práce“ a ve třetím „přijde únava“.

21 Rozdíl v názorech občanů a představitelů se pravděpodobně objevuje častěji ve větších městech, jak napovídá starší př́ípadová studie Hanšpacha z Liberce (1997).

22 Nutno dodat, že názory vůdců se často podobaly pohledu vzdělanějších občanů, ke kterým svým vzděláním náležejí. Rovnostářské postoje veřejnosti pravděpodobně z části odrážely situaci oslabení hospodářství a rostoucí nezaměstnanosti. 
dříve či později narazil na překážku v podobě rozdrobené územní správy. ${ }^{23}$ Řada vesměs ekonomických nástrojů (např́iklad rozpočtové určení daní) se po delší dobu snaží povzbuzovat slučování obcí, avšak doposud se míjela účinkem. Novela zákona o obcích alespoň ztížila možnost osamostatnění dalších obcí, ke kterému však v posledních letech docházelo již jen zcela výjimečně. Při výzkumech mezi představiteli obcí se opakovaně ukazuje, že se slučováním obcí souhlasí ti, kterých by se nedotklo, tzn. větší obce. Naopak starostové menších obcí se většinou takovým vyhlídkám brání. Jedna strana argumentuje ekonomickou efektivitou, druhá se brání odkazem na Ústavou zaručená práva obcí a jejich orgánů (Ryšavý 2006b).

Zdá se, že to nebude sebelepší ekonomická nabídka, co nakonec rozhodne o postupné integraci malých obcí, ${ }^{24}$ ale vyčerpání lidského potenciálu. Nápor povinností, které musejí obecní úřady plnit, je značný a v čase spíše roste. Kapacita učit se jim a provádět je má své meze. V řadě obcí se při každých obecních volbách stává problémem najít dost ochotných kandidátů. Tento vývoj ohrožuje jeden z hlavních výdobytků sametové revoluce, kterým je soutěž ve svobodných volbách (Ryšavý 2006c). Zvláště v malých obcích se tak může první generace lídrů stát zároveň i generací poslední. Ve větších a př́ípadně integrovaných obcích lze očekávat rostoucí odlišnost postojů veřejnosti a lokálních reprezentací.

Přijmeme-li rozchod názorů obyvatel obcí a jejich představitelů jako hypotetický mezník dvou generací lokálních politiků, pak je třeba hledat spojující rysy nastupující generace. Na rozdíl od první může být pro vedení obcí lépe připravená, nebot' má možnost učit se z úspěchů i chyb svých předchůdců. Zdaleka ne vždy přitom musí dojít ke generačním konfliktům a vymezování se vůči generaci první. Jak napovídají rozhovory s představiteli obcí, př́slušníci první generace často chtěli připravit či dokonce vychovat své nástupce tak, aby při jejich odchodu nedošlo k narušení kontinuity toho, oč usilovali. Některým se to více či méně podařilo, jiní přiznali svůj nezdar a smiřrovali se s tím, co přinese čas. ${ }^{25}$ Někde po dvou třech relativně klidných volebních obdobích došlo k ostrému, obvykle výrazně personalizovanému střetu a nahrazení dosavadního vedení radnice novým (Ryšavý 2006a).

Nastupující lídři už zřejmě nebudou považovat za svůj prvořadý úkol sehnat milionové dotace na plynofikaci obce či budování kanalizace. Snad se pustí do příslovečných „rozkopaných chodníků“, které zůstávají po investicích do podzemní infrastruktury. Nezdá se také, že by s nástupem služebně mladších reprezentantů obcí oslaboval nepolitický charakter lokální politiky, jak to očekávali výzkumníci obnovené samosprávy. Význam politických stran vzrostl ve větších obcích, ale žádný výrazný trend patrný není. Zvláště představitelé

23 V tomto ohledu se Česká republika umist’uje na opačném konci kontinua zemí než Polsko.

24 Může jít přitom bud' o integraci strukturní, tzn. slučování obcí, nebo méně radikální integraci funkční, při níž se přenáší některé funkce (působnosti) na větší obce (Illner 2006b).

25 „Jde o člověka, který je v radě, ve finanční komisi, ,u všeckýho je...', snaží se, ale záleží na lidech.“ Tak popisoval místostarosta jedné ze středomoravských obcí nedlouho před obecními volbami v roce 2006 vyhlédnutého nástupce, který posléze získal absolutně nejvyšší počet hlasů a byl zvolen starostou. Kontinuitu utvrzuje jeho zástupce již důchodového věku, který od roku 1990 vystřídal pozice radního, místostarosty i starosty. Jiný př́íklad uvedla již citovaná starostka, kterou trápilo, že nevěděla, kdo přijde po ní. V jednom z volebních období v zastupitelstvu byla „výborná mladá žena“, ze které chtěla udělat starostku. Na konci ji ta žena prosila, at' ji nenutí znovu kandidovat. Zřejmě z toho měla problémy v rodinném klanu. 
menších obcí se zřetelně vymezují proti „politikaření“, které podle nich vládne na centrální úrovni. Členství v politické straně i nadále nepovažují za důležitou výbavu reprezentanta obce a nebrání se tomu, když v radě obce získají po volbách zastoupení všechny nebo téměř všechny volební strany (Ryšavý 2006a).

Generační spř́izněnost, objeví-li se jaká, bude spíše spojena s důrazem na využívání manažerských a komunikačních strategií jednak uvnitř místních politických elit, jednak v působení reprezentace obce vůči vlastním občanům a okolnímu prostředí. ${ }^{26}$ Inspirací bude $\mathrm{v}$ mnohých oblastech svět byznysu - při prezentaci obce na internetu, zavádění prvků e-governmentu či hodnocení kvality nabízených služeb. ${ }^{27}$ Ideou nejednoho starosty je „udělat $\mathrm{z}$ města firmu“.

\section{Nástup regionálních politiků - opěł první generace?}

Nové regionální elity se ustavovaly v podmínkách, které se $\mathrm{v}$ mnoha ohledech lišily od situace prvních reprezentantů obcí. Jen obtížně bychom hledali souvislost mezi bývalými krajskými národními výbory a dnešními orgány krajủ. Jako převodní páky komunistické moci byly krajské národní výbory zrušeny v roce 1990 bez náhrady. Politické a symbolické důvody prritom vážily více než ohled na výkon části administrativní agendy, pro niž by regionální úroveň byla nejracionálnější (Illner 1997). Desetiletý časový odstup posílil autonomní a samosprávnou složku nově konstituovaných krajů. Přebírání agendy nemohlo být ovšem tak automatické jako na lokální úrovni na začátku devadesátých let minulého století. Četné spory kolem pravomocí, zodpovědnosti a úhrad se týkaly především oblasti stř̌edního školství a zdravotnictví a posléze vytvářely tlak na zefektivňování systému alespoň na úrovni krajů. Stručně řečeno, $\mathrm{z}$ institucionálního pohledu došlo $\mathrm{v}$ regionální politice $\mathrm{k}$ výrazné diskontinuitě.

V rovině osobních zkušeností a personálního složení převládla po prvních krajských volbách v roce 2000 naopak kontinuita. Zkoumání politických drah vedlo k závěru, že většina z krajských zastupitelů má zkušenosti s obecní samosprávou. Nejvyšší pozice v krajích získali nejčastěji dosavadní starostové či jiní lokální politici nebo bývalí vysocí úředníci okresních úřadů (Čermák 2005). Jde o logický výsledek tehdejší situace. Z jedné strany vymezil parlament podobu regionální samosprávy a její pravomoci, na druhé straně mohli personální složení rodících se krajských politických elit podstatným způsobem ovlivnit politici lokální. $\mathrm{V}$ této skupině potenciálních kandidátů $\mathrm{s}$ nabytými zkušenostmi početně převažovali představitelé menších obcí. Lídři větších měst zase mohli snáze projít sítem voleb,

26 Západočeský starosta popisoval práci člověka, který se stará o komunikaci s veřejností. Jeho úkolem je vytvářet celkový dojem při realizaci politiky radnice. Jde o to, aby se realizované akce patřičným způsobem dostávaly do povědomí obyvatel.

27 Vedení jednoho z východočeských měst se chtělo vyrovnat s problémem, jak zajistit průhlednost procesủ, které mají vliv na dění ve městě, a efektivnost investic. Proto se spolu s dalšími městy zapojilo do projektu Společný hodnotící rámec (CAF). V zastupitelstvu se zásadní věci vyjednávají tak důkladně a dlouho, až je odsouhlasí všichni. Lidé ve vedení obce jsou podle slov tajemníka někdy obviňováni z toho, že zabili opozici. 
pokud o to stáli. Výsledek byl relativně vyrovnaný. Výběrové šetření ukázalo, že „velká část z nich [tj. krajských politických elit, pozn. DR] bydlí ve městech a obcích s méně než 20 tisíci obyvateli, takže nejsou reprezentanty jen největších měst př́islušného kraje“ (Kostelecký a kol. 2006: 158).

Oproti lokální politice však v krajích podstatně zesílil prvek stranickosti. Zákonodárci ve snaze zabránit vstupu nezávislých do krajských zastupitelstev omezili volební soutěž na kandidaturu politických stran a hnutí. Část lokálních politiků reagovala těsně před prvními krajskými volbami v roce 2000 registrací Sdružení nezávislých kandidátů jako politického hnutí, které zčásti uspělo ve třech krajích. $\mathrm{V}$ dalších krajích získala několik mandátů podobná hnutí: Nezávislí, Nezávislí pro Moravu a Zlínské hnutí nezávislých. Původní záměr tak spíše vedl $\mathrm{k}$ vyšší formalizaci do té doby velmi volných sdružení opírajících se z velké části o zkušené lokální politiky. Druhé volby ukázaly ještě přesvědčivěji, že do regionální politiky nelze téměř vstoupit bez zázemí v politické straně.

Ač jsou regionální politici s lokální politikou úzce svázáni, přece jenom je lze jako celek zřetelně odlišit váhou členství v politické straně. Při vymezení vůči národní politice sehrál důležitou roli fakt, že šest let stály spíše pravicové reprezentace krajů v opozici k levicové či středo-levé vládě. Řada třecích ploch vznikla také při přebírání pravomocí, dohadovaní finančních zdrojů atd. Představitelé krajů se také pozvolna prosazují ve vedení svých mateřských stran. Jak a v čem se lišili první regionální politici od ostatních občanů?

Z šetření Regionální elity z roku 2004 vyplývá, že reprezentanti krajů vykazovali v porovnání s českou populací výrazně vyšší generalizovanou i institucionalizovanou důvěru, tzn. důvěru v druhé lidi obecně a důvěru v různé instituce (Stachová 2005). Zároveň jim, zdá se, nechyběla sebedůvěra. Př́slušníci krajských politických a administrativních elit chtěli výrazněji ovlivňovat faktory ekonomického rozvoje krajů. Stavěli se na obranu své vlastní autonomie proti zasahování zvenčí. Více než tři čtvrtiny krajských zastupitelů dotázaných před druhými krajskými volbami mělo za to, že se krajské zřízení osvědčilo. V šetření Naše společnost (CVVM) $\mathrm{z}$ téže doby se proti tomu více než polovina občanů nedokázala $\mathrm{k}$ této otázce vyjádřit nebo odmítla odpovědět. Zbývající část se rovnoměrně rozdělila mezi spokojené a vǔči krajskému zř́zení kritické hlasy (Illner 2005).

Mají-li první reprezentace krajů něco společného a specifického, pak je to vysoké a zřejmě dále rostoucí sebevědomí, které se přinejmenším zčásti opírá o př́edchozí zkušenosti z lokální politiky či bývalých okresních úřadů. Vypovídá o něm už samotná ochota vstoupit do klání o pozice, s nimiž v počátku novodobé existence krajů málokdo spojoval větší očekávání. Občané se obávali nákladnosti, národní politici zase ztráty svého vlivu. Při relativně nízkém zájmu médií se lídři krajů nesnaží vyhovět veřejnému mínění do té míry, jakou často předvádí vláda i špičky opozičních stran. $\mathrm{V}$ oblastech spadajících pod jejich pravomoc tak spíše dochází ke změnám, které nemusí být všem po vůli. Příští léta slibující př́liv peněz $\mathrm{z}$ evropských fondů mohou vést ke hmatatelnějším výstupům regionální politiky. Otevřená zůstává otázka, zda se s touto podporou stanou reprezentace krajů jen novou generací budovatelů, či zda napomohou k výchově lídrů, jejichž sebevědomí nekončí na hranicích krajů či státu, ale překračuje je k jejich evropským partnerům. 


\section{Závěr}

Michael Corsten (1999) zdůvodňuje zájem o téma generací krizí kolektivních identit a při tom zmiňuje i pád socialismu jako alternativního modelu modernizace. Úvodní citát z prohlášení Občanského fóra ukazuje, že onen pád socialismu provázela silná potřeba překlenout různá dělítka, neutralizovat možné konkurenční zdroje identit, at' už založená na věku, etnické příslušnosti, či statusu. Občanské fórum chtělo podle uvedeného prohlášení zajistit dialog veřejnosti s mocí a vést svobodnou a věcnou diskusi o reálných cestách ke změně politických a hospodářských poměrů v naší zemi.

Od diskusí o změnách v politické a ekonomické sféře nebylo daleko k činům, jejichž logiku se snažila objasnit řada teorií a výzkumů. Nemalá část z nich zdůraznila klíčovou roli politických a ekonomických elit. Při zkoumání jejich proměn a chování jejich členů byl brán zřetel také na věk a generační blízkost těchto členů, často ovšem v úzce biologickém slova smyslu. V této zjednodušené podobě lze donekonečna potvrzovat nebo vyvracet množství „generačních“ hypotéz, aniž by to vedlo ke ztrátě relevance a inspirativnosti původního Mannheimova př́spěvku k otázce generací s jeho terminologickým bohatstvím.

Při hledání specifických rysů, které by opravňovaly označit první reprezentanty obcí a posléze představitele samosprávných krajů za generační souputníky, nestál v tomto textu na prvním místě věk ani zkušenosti z formativních let. Pojítkem první generace lokálních politiků naopak byla ne-zkušenost a ještě výrazněji uvědomovaná a v různém rozsahu realizovaná potřeba učit se mnoha novým rolím, které se vstupem do místní politiky souvisely. Zvláště na lokální úrovni šlo spíše o „přebudovávání organizací a institucí ne na ruinách, ale s ruinami komunismu“ (Stark 1996: 995) než o stavbu na zelené louce. Na počátku působení lokálních elit stál často návrat ke ztracené samostatnosti obce. Indikátorem odchodu první generace lídrů a nástupu generace nové může být rostoucí propast mezi názory a postoji občanů na jedné a jejich místních reprezentanti̊ na druhé straně. Nechut’ a nezájem širšího okruhu občanů angažovat se v místních záležitostech otevřely prostor pro takový názorový rozchod. Chybí ovšem doklady, zda k němu skutečně došlo či dochází. Otázkou blízké budoucnosti také zůstává, zda se v řadě nejmenších obcí první generace místních politiků nestane zároveň generací poslední.

Oč zřetelnější je diskontinuita institucí na regionální úrovni, o to méně zř̌etelná jsou specifika první ,generace“ krajských reprezentací. Jejich příslušníci se vyznačují relativně vysokou mírou sebevědomí a důvěry, akumulovanou zkušeností z místní politiky. Na rozdíl od lokální politiky v nich naprosto dominují členové politických stran a hnutí. Fáze vymezování se vůči nejvyššímu patru politiky přechází do stádia, v němž se z úspěšných regionálních politiků rekrutují kandidáti do špičkových pozic mateřských stran. Postupné etablování se regionálních politických elit mění podobu českého politického systému a nepochybně $\mathrm{v}$ budoucnosti povede $\mathrm{k}$ dalším proměnám jeho podoby jak na lokální, tak na národní úrovni. Samotné kraje podstatně ovlivňuje evropská přítomnost akcentující roli substátních celků. Generace regionálních politiků má tak před sebou spíše období vnitřního členění než konec historie. 


\section{Literatura}

Baldersheim, H.; Illner, M.; Offerdal, A.; Rose, L.; Swianiewicz, P. (eds.) 1996. Local Democracy and the Processes of Transformation in East-Central Europe. Boulder, CO, Oxford: Westview Press.

Baldersheim, H.; Illner, M. 1996. „Virtuous Circles: Local Democracy?“ In a Post-Communist Environment.“ In H. Baldersheim, M. Illner, A. Offerdal, L. Rose, P. Swianiewicz (eds.) Local Democracy and the Processes of Transformation in East-Central Europe. Boulder, CO, Oxford: Westview Press, s. 225-240.

Balík, S. 2003. „Vývoj obecního volebního práva od roku 1848 do současnosti.“ In S. Balík (ed.) Komunální volby v České republice v roce 2002. Brno: Masarykova univerzita, Mezinárodní politologický ústav, s. 12-25.

Becker, H. A. 1992. „A Pattern of Generations and its Consequences.“

In H. A. Becker (ed.) Dynamics of Cohort and Generations Research. Amsterdam: Thesis, s. 219-248.

Best, H.; Becker, U. (eds.) 1997. Elites in Transition: Elite Research in Central and Eastern Europe. Opladen: Leske + Budrich.

Bozóki, A. 2003. „Theoretical Interpretation of Elite Change in East Central Europe.“ In křestní M. Dogan (ed.) Elite Configurations at the Apex of Power. Leiden, Boston: Brill, s. 215-247.

Corsten, M. 1999. „The Time of Generations.“ Time \& Society, 8(2): 249-272.

Čermák, D. 2005. „Politické dráhy regionálních elit.“'In T. Kostelecký, J. Vobecká (eds.) Regionální elity 2004. Praha: Sociologický ústav AV ČR, pp. 29-37.

De Vries, M. S. 2005. „Changing Policy Views at the Local Level: The Effect of Age, Generations and Policy-Periods in Five European Countries." European Journal of Political Research, 44:1-15.

Frič, P., Nekola, M., Prudký, L. 2005. Elity a modernizace. Praha: UK FSV CESES.

Hanley, E.; Matějů, P.; Vlachová, K.; Krejčí, J. 1996. The Making of Post-Communist Elites in Eastern Europe. Working Papers 96: 3. Prague: Institute of Sociology ASCR.

Hanšpach, D. 1997. Political Organizational and Policy Transformation at the Municipal Level: The Case of Liberec. Praha: Sociologický ústav AV ČR.

Haukanes, H. 2004. Velká dramata - obyčejné životy. Praha: SLON.

Ingelhart, R. 1977. The Silent Revolution, Changing Values and Political Styles among Western Publics. Princeton: Princeton University Press.

Illner, M. 1992. „Continuity aned Discontinuity. Political Change in a Czech Village after 1990.“ Czech Sociological Review 28 (Special Issue): 79-91.

Illner, M. 1997. „Territorial Decentralisation - A Stumbling Block of Democratic Reforms in East-Central Europe?" Polish Sociological Review, 117: 23-45.

Illner, M. 2001. „Formování lokálních mocenských elit se zvláštním zřetelem na úlohu starostů.“ In M. Hampl a kol. Regionální vývoj: specifika české transformace, evropská integrace a obecná teorie. Praha: DemoArt pro PřF UK v Praze, s. 251-274.

Illner, M. 2005. „Názory na nové krajské zřízení.“ In T. Kostelecký, J. Vobecká (eds.) Regionální elity 2004. Praha: Sociologický ústav AV ČR, s. 77-88. 
Illner, M. 2006a. „Úvod.“ In Z. Vajdová, D. Čermák, M. Illner (eds.) Autonomie a spolupráce: di̊sledky ustavení obecního zrrizení v roce 1990. Praha: Sociologický ústav, s. 11-13.

Illner, M. 2006b. „Velikost obcí, efektivita jejich správy a lokální demokracie.“ In Z. Vajdová, D. Čermák, M. Illner (eds.). Autonomie a spolupráce: důsledky ustavení obecního zř́zení v roce 1990. Praha: Sociologický ústav, s. 15-26.

Kabele, J. 2004a. „Polistopadové proměny filipovské radnice.“ In J. Kandert (ed.) Jihomoravský venkov po socialismu. Praha: Matfyzpress, s. 73-116.

Kabele, J. 2004b. „O vládnutí na místní úrovni.“ In J. Kandert (ed.) Jihomoravský venkov po socialismu. Praha: Matfyzpress, s.199-212.

Kabele, J. 2004c. „Přerodové procesy ve Filipově a v české společnosti.“ In J. Kandert (ed.) Jihomoravský venkov po socialismu. Praha: Matfyzpress, s. 226-257.

Kabele, J. 2005. Z kapitalismu do socialismu a zpět. Praha: Karolinum.

Kandert, J. (ed.). 2004. Jihomoravský venkov po socialismu. Praha: Matfyzpress.

Kostelecký, T., Čermák, D., Vobecká, J. 2006. „Druhé volby do krajských zastupitelstev - kontinuita nebo změna?" Evropská volební studia 1(2): 136-160.

Machonin, P., Tuček, M., Hartoš, P., Nekola, M.. 2006. „České ekonomické a politické elity po 15 letech postsocialistické transformace." In Tuček, M. a kol. České elity po patnácti letech transformace. Praha: Sociologický ústav AV ČR, s. 39-70.

Malíková, L. 1997. „Starostovia (primátori) na Slovensku a ich postoje k zmenám v miestnej samospráve.“ Sociológia 29(4): 405-426.

Mannheim, K. 1952. „The Problem of Generations.“ In P. Kecskemeti (ed.). Essays on the sociology of knowledge by Karl Mannheim. London: Routledge \& Kegan Paul Ltd., s. $276-322$.

Offerdal, A., Hanšpach, D., Kowalczyk, A., Patočka, J. 1996. „The New Local Elites.“ In H. Baldersheim, M. Illner, A. Offerdal, L. Rose, P. Swianiewicz (eds.) Local Democracy and the Processes of Transformation in East-Central Europe. Boulder, CO, Oxford: Westview Press, s. 105-140.

Pfaff, Stephen. 1996. „Collective Identity and Informal Groups in Revolutionary Mobilization: East Germany in 1989.“ Social Forces 75: 91-118.

Ryšavý, D. 2004. „Filipovský průmysl a podnikání v obchodě a ve službách.“ In J. Kandert (ed.) Jihomoravský venkov po socialismu. Praha: Matfyzpress, s. 117-136.

Ryšavý, D. 2006a. „Komunální je komunální a velká je velká! K hypotéze politizace lokálních politických elit.“ Sociologický časopis 42(5): 683-699.

Ryšavý, D. 2006b. „Mikroregiony jako dobrovolné svazky obcí vs. model společenství obcí?“ In D. Ryšavý (ed.) Acta Universitatis Palackianae Olomucensis. Facultas Philoshophica. Socilogica-Andragogica, s. 129-145.

Ryšavý, D. 2006c. „Changes in the Local Political Elite in Small Town and Rural Areas. Does Revolution Devour Its Children?" East European Countryside 12: 51-65.

Stachová, J. 2005. „Důvěra a občanská angažovanost regionálních elit.“ In T. Kostelecký, J. Vobecká (eds.). Regionální elity 2004. Praha: Sociologický ústav AV ČR, s. 69-76.

Stark, D. 1996. „Recombinant Property in East European Capitalism.“ American Journal of Sociology 101: 993-1027. 
Surazska, W. 1996. „Local Revolutions in Central Europe, 1990 to 1994: Memoirs of Mayors and Councilors from Poland, Slovakia and The Czech Republic." Publius 26(2): 121-140.

Szalai, E. 1994. „The Power Structure in Hungary after the Political Transition.“ In Ch. G. A. Briant, E. Mokrzycki (eds.). The New Great Transformation? Change and Continuity in East-Central Europe. London: Routledge, s. 120-143.

Szelényi, I. 1988. Socialist Entrepreneurs. Madison: University of Wisconsin Press.

Szelenyi, I., Treiman, D. 1991. „Vývoj sociální stratifikace a rekrutace elit ve východní Evropě po roce 1989: Výzkumný projekt.“ Sociologický časopis 27: 276-298.

Tessler, M., Konold, C., Reif, M. 2004. „Political generations in developing countries.“ Public Opinion Quarterly 68(2): 184-216.

Tuček, M. 1996. „Vytváření nové elity.“ In P. Machonin, M. Tuček a kol. Česká společnost $v$ transformaci. Praha: SLON, s. 154-167.

Vajdová, Z., Čermák, D. 2006. „Územní změny obcí v ČR od roku 1990.“ In Z. Vajdová, D. Čermák, M. Illner (eds.). Autonomie a spolupráce: důsledky ustaveni obecního zř́zení v roce 1990. Praha: Sociologický ústav AV ČR, s. 27-37.

Wiatr, J. J. 2003. „Polish local elites and democratic change, 1990-2002.“ Communist and Post-Communist Studies 36: 373-383.

\section{Autor}

Dan Ryšavý vyučuje na Katedře sociologie a andragogiky FF UP v Olomouci ekonomickou sociologii, kvantitativní analýzu dat a také kurz Politické elity ve střední Evropě. Zabývá se především výzkumem lokálních a regionálních elit, spolupráce mezi obcemi a proměn různých úrovní samosprávy. Kontakt: rysavyd@ffnw.upol.cz 